\title{
PERPINDAHAN PANAS DAN MASSA PADA PENGEMBUNAN CAMPURAN METANOL-PROPANOL-UDARA DALAM KONDENSOR TEGAK
}

\author{
Sarto*), Bambang Soehendro, I Made Bendiyasa dan Rochmadi \\ Jurusan Teknik Kimia Fakultas Teknik UGM \\ Jl. Grafika No. 2 Yogyakarta, Telp.: (0274)902171, Fax : (0274)902170 \\ ${ }^{*}$ Penulis korespondensi: sarto@chemeng.ugm.ac.id
}

\begin{abstract}
Abstrak
Pengembunan campuran uap dan gas melibatkan mekanisme perpindahan panas dan massa secara simultan yang sangat rumit sehingga pendekatan teoritis terhadap peristiwanya belum cukup untuk diterapkan pada perancangan kondensor. Penelitian ini dimaksudkan untuk memperoleh persamaan semi-empirik yang sederhana dan cukup teliti sebagai dasar memperkirakan koefisien perpindahan panas dan massa proses pengembunan campuran metanol(1)-propanol(2)-udara. Percobaan pengembunan dilakukan di dalam kondensor pipa ganda tegak sepanjang 1,7 m. Ukuran pipa luar dan dalam berturut-turut sebesar $50 \mathrm{~mm}$ dan $25 \mathrm{~mm}$. Campuran uap dan gas dialirkan dari atas melalui anulus sedangkan air pendingin dialirkan di dalam pipa dari bawah sehingga sistem menjadi berlawanan arah. Data percobaan meliputi kecepatan alir dan suhu air pendingin, komposisi dan suhu campuran uap-gas, kecepatan alir dan suhu kondensat, kecepatan alir udara, dan tekanan sistem. Koefisien perpindahan panas dan massa dievaluasi melalui model matematik yang disusun berdasarkan neraca massa dan panas yang diselesaikan secara simultan. Hasil penelitian dinyatakan dalam bentuk bilangan tak berdimensi yaitu $N u=19,9297(1-y n)^{2,9164} \operatorname{Re}^{0,8142} \mathrm{Pr}^{1 / 3}$. Adapun hubungan fungsional bilangan Sherwood yang merupakan bentuk bilangan tak berdimensi koefisien perpindahan massa dinyatakan dengan persamaan $S_{1}=15,1042\left(1-y_{n}\right)^{2,9696} \operatorname{Re}^{0,8068} \mathrm{Sc}^{1 / 3}$ dan $\mathrm{Sh}_{2}=5,7227(1$ $\left.y_{n}\right)^{2,9916} \operatorname{Re}^{0,8113} \mathrm{Sc}^{1 / 3}$
\end{abstract}

Kata kunci: kondensor tegak, metanol-propanol-udara, perpindahan panas dan massa

\begin{abstract}
Condensation of vapor-gas mixtures is a complicated simultaneous heat and mass transfer processes. Theoretical studies on condensation of vapor and gas mixtures have been done extensively, but they have not given satisfactory results yet. The objective of the research is to determine semi-empirical equations, which are simple and accurate enough, to be used for estimating the heat and mass transfer coefficients in methanol(1)-propanol(2)-air mixture condensation. The experiments were conducted in a vertical double pipe condenser of $1.7 \mathrm{~m}$ length. The inner and outer pipe sizes were, $25 \mathrm{~mm}$ and $50 \mathrm{~mm}$, respectively. The mixture of vapors and gas contacted with cooling water in counter-current flow. The experimental data consisted of flow-rates and temperatures of the cooling water, compositions and temperatures of the mixture of vapors and gas, flow-rates and temperatures of condensate, air flowrates, and pressures of the system. Heat and mass transfer coefficient were evaluated through mathematic model based on heat and mass balances that is simultaneously solved. The experimental results are presented in the form of non-dimensionless number as follows Nu=19.9297(1$y n{ }^{2.9164} \mathrm{Re}^{0.8142} \mathrm{Pr}^{1 / 3}$ In addition functional relationship between Sherwood number with Reynolds number of vapors-gas mixture, Schmidt number of vapors-gas mixture, and gas mole fraction were stated by equation $S h_{1}=15,1042\left(1-y_{n}\right)^{2.9696} R^{0.8068} \mathrm{Sc}^{1 / 3}$ and $\mathrm{Sh}_{2}=5.7227\left(1-y_{n}\right)^{2.9916} \mathrm{Re}^{0.8113} \mathrm{Sc}^{1 / 3}$
\end{abstract}

Keywords: standing condenser, methanol-propanol-air, mass and heat transfer

\section{PENDAHULUAN}

Pengembunan campuran uap yang mengandung gas sering dijumpai di industri. Penelitian mengenai pengaruh gas pada proses pengembunan telah banyak dilakukan. Pengaruh tersebut diantaranya adalah penurunan koefsien perpindahan panas rerata pada pengembunan campuran uap air dan udara (Lee et al., 2001) dan meningkatkan hambatan permukaan dan 
menurunkan estimasi nilai koefisien pengembunan (Takaharu and Yurika, 2003), mempengaruhi kurva karakteristik perpindahan kalor kondensasi terutama pada daerah hambatan difusi pada pengembunan campuran uap-air, etanol dan udara (Wang and Utaka, 2004; Wang and Utaka, 2005). Pada pembangkit listrik tenaga panas bumi, keberadaan gas mempengaruhi kinerja termodinamiknya (Gokcen and Yildirim, 2008).

Pendekatan perancangan kondensor campuran uap dan gas dapat dikelompokkan menjadi 2 model, yaitu model setimbang (equilibrium model) dan model tidak setimbang (nonequilibrium model). Fenomena pengembunan uap yang mengandung gas lebih dapat dijelaskan dengan model tak setimbang daripada model setimbang karena kemungkinan terjadinya perbedaan suhu antara badan uap-gas dengan suhu batas antarmuka semakin besar. Model tak setimbang berdasarkan model lapisan yang diajukan oleh Colburn dan Drew (1937) dalam Toor (1964). Pengembangannya terletak pada mekanisme perpindahan massanya yang dapat dikelompokkan menjadi 3, yaitu Model Difusivitas Efektif (Schrodt, 1973), Model Linear (Toor, 1964), dan Model Interaksi (Krishna and Panchal, 1977; Burghardt and Berezowski, 1992; Mazzarotta and Sebastian, 1995). Interaksi antara senyawa yang mendifusi dalam campuran multikomponen sangat berperan dalam perancangan sistem perpindahan massa multikomponen (Behren et al., 1972).

Webb dan Sardesai (1981) membandingkan manfaat teori pengembunan multikomonen, seperti cara Krishna-Standart (1976), Teori Terlinear Toor (1964), dan Model Difusivitas Efektif berdasarkan Colburn dan Hougen dengan hasil percobaan. Sistem yang dipelajari adalah campuran isopropanol-airrefrigeran dan isoproanol-air-nitrogen. Hasil prediksi penurunan suhu gas, cara Krishna-Standart memberikan hasil yang tidak banyak berbeda yaitu sekitar 5\%. Model Difusivitas Efektif menghasilkan prediksi penurunan suhu yang mencapai 20\% lebih besar daripada hasil percobaan. Untuk kecepatan pengembunan air, Model Interaksi memberikan hasil yang lebih jelek daripada Model Difusivitas Efektif, yaitu mencapai sekitar 15\%. Akan tetapi, untuk kecepatan pengembunan isopropanol, Model Difusivitas Efektif memberikan hasil yang paling jelek yaitu menyimpang sampai $30 \%$ untuk Sistem isopropanol-air-refrigeran dan 15\% untuk isopropanolair-nitrogen.

Perbandingan hasil percobaan Webb dan Sardesi (1981) dengan prediksi Furno (1986) dalam Taylor dan Krishna (1993) menunjukkan bahwa prediksi komposisi embunan menyimpang sampai sekitar 37\% dari data percobaan. Taylor dan Krishna (1993) juga membandingkan kecepatan perpindahan massa overall percobaan perpindahan massa dalam kolom dinding terbasahi sistem aseton-benzennitrogen/helium oleh Modine (1963) dengan prediksi oleh Krishna (1981a) dan Furno (1986) dengan hasil penyimpangan terbesar untuk prediksi Model Interaksi dan Model Difusivitas Efektif berturut-turut sekitar $25 \%$ dan $60 \%$.

Pemakaian model perpindahan massa dengan pengabaian interaksi, cenderung memberikan penyimpangan yang lebih besar, sementara masuknya interaksi difusional akan memperumit model. Jika analisis pengembunan seakan-akan dilakukan dengan model tanpa interaksi, yang kemudian disebut Model Perpindahan Kalor Linear Terkoreksi, dengan nilai koefisien perpindahan kalor dan massa diperoleh dari percobaan, maka akan diperoleh hasil yang lebih realistik dengan cara yang lebih sederhana (Sarto dkk, 2002). Model tersebut telah diaplikasikan untuk Sistem etanol-benzen-udara (Sarto dkk, 2002), etanoltoluen-udara (Sarto dkk, 2008(a), dan metanol-airudara (Sarto dkk, 2008(b), dengan hasil berupa hubungan bilangan tidak berdimensi baku untuk perpindahan kalor dan massa.

Penelitian eksperimental pengembunan campuran metanol-propanol-udara perlu dilakukan karena mempunyai perbedaan sifat komponen uap, seperti titik didih, difusivitas, polaritas, dan panas pengembunan. Pada makalah ini disampaikan hasil penelitian pengembunan campuran sistem tersebut dengan membandingkan sistem etanol- benzen-udara, etanol-toluen-udara, dan metanol-air-udara.

\section{METODE PENELITIAN}

Rangkaian alat percobaan dapat dilihat pada Gambar 1. Alat yang digunakan dapat dibagi menjadi 3 kelompok yaitu alat utama, alat pendukung, serta alat ukur dan pengatur.

Alat utama terdiri atas 2 buah boiler dan kondensor uji. Alat pendukung terdiri dari fasilitas pipa terisolasi, penyedia air pendingin, udara, listrik, dan kondensor akhir. Adapun alat ukur dan pengatur yang digunakan meliputi termokopel, transduser tekanan, pengukur tebal, flowmeter air, flowmeter udara, silinder pengukur kondensat, katub, dan pemanas. Boiler dirancang dengan kapasitas 18 liter cairan dan dilengkapi 4 buah pemanas listrik, masingmasing dengan kapasitas 2.000 watt.

Kondensor berupa 2 pipa konsentrik (double pipe exchanger), masing-masing berdiameter 25 dan $50 \mathrm{~mm}$, dengan panjang 1,7 meter. Di samping kedua pipa tersebut, terdapat pipa tembaga yang dimasukkan ke dalam pipa dalam, yang berfungsi sebagai pemegang 6 termokopel untuk mengukur suhu air pendingin.

Dinding pipa kecil diukur suhunya dengan menempelkan 5 termokopel secara elektrokimia, sedangkan suhu uap diukur dengan 7 buah termokopel. Termokopel yang digunakan adalah jenis $\mathrm{T}$, dengan ukuran untuk termokopel boiler, temokopel uap-gas, termokopel untuk dinding kondensor, dan termokopel untuk air pendingin berturut-turut sebesar 0,$67 ; 0,5 ; 0,33$; dan $0,1 \mathrm{~mm}$. 


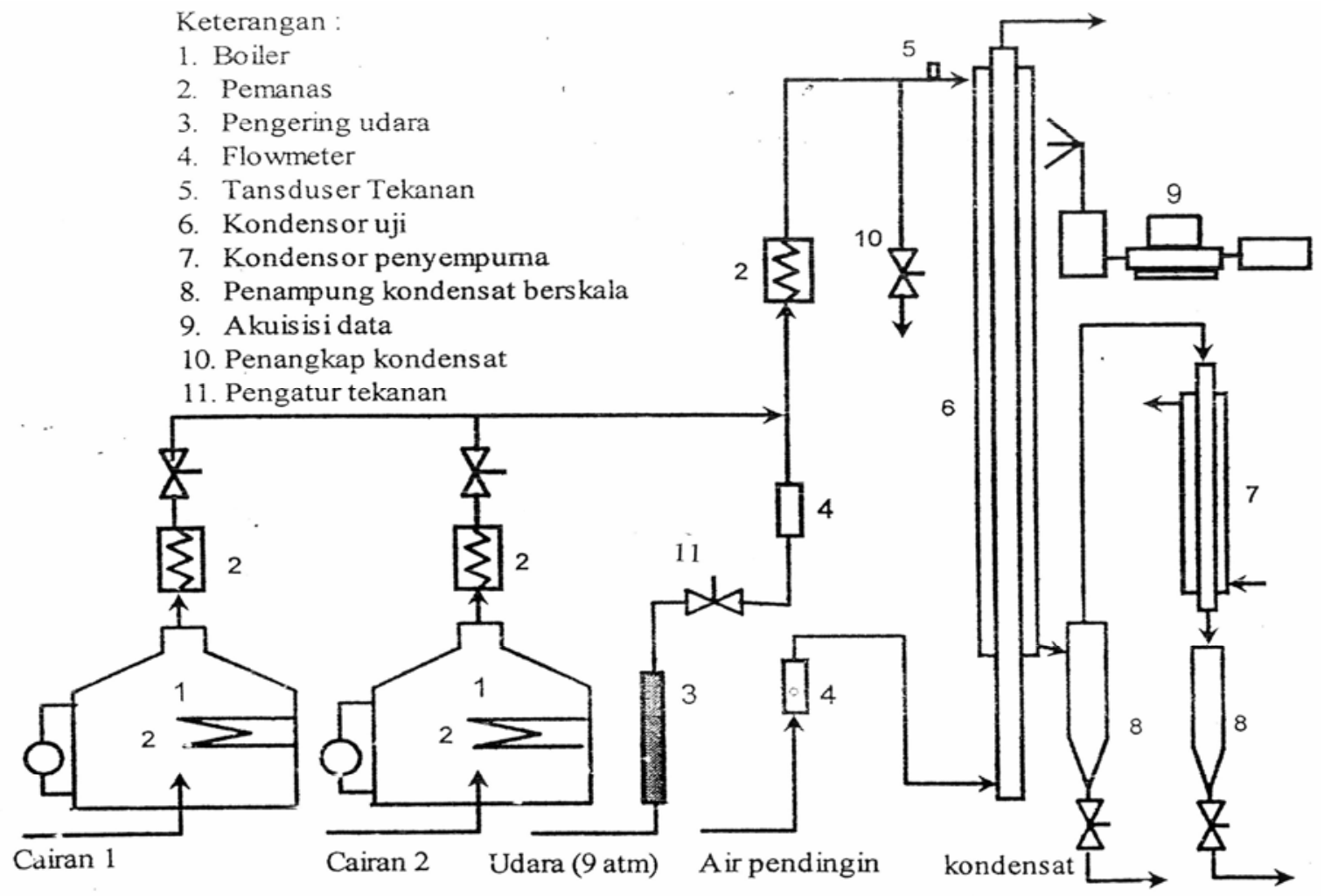

Gambar 1. Rangkaian alat percobaan pengembunan campuran metanol-propanol-udara

Pengukuran suhu dilakukan secara otomatis menggunakan perangkat akuisisi data yang terdiri atas perangkat keras (hardware) seperti mainframe HP3852a produksi Hewlett Packard Company, Komputer PC 486, Monitor VGA color, HP-IB Card HP82335, dan printer dot matrix 9 pin (Epson LX800), serta perangkat lunak (software) berupa paket program. Pada sistem ini tersedia 20 saluran, yang kesemuanya dipakai untuk memantau suhu, yaitu 7 posisi suhu uap, 5 posisi suhu dinding kondensor, 6 posisi suhu air pendingin, dan 2 suhu boiler. Pipa luar dilubangi sebanyak 7 buah untuk pengambilan cuplikan uap dan gas.

Perangkat akuisisi data tidak hanya berfungsi untuk pengambilan data suhu tetapi juga untuk memantau keadaan proses yaitu untuk memastikan proses telah mencapai keadaan ajeg (steady state). Oleh karena itu, pengaktifannya dilakukan sebelum pengukuran terhadap peubah-peubah proses. Air pendingin dialirkan dan diatur untuk memperoleh debit tertentu dalam keadaan ajeg. Penguapan bahan diawali dengan pemanasan pendahuluan, yaitu dengan menghidupkan semua pemanas boiler. Pemanas pendahuluan ini dilakukan sampai suhu bahan mencapai titik didihnya. Sementara itu, debit dan tekanan udara diatur dengan regulator dan katup. Pengukuran peubah operasi dan pengambilan sampel campuran uap-gas dilakukan setelah keadaan ajeg tercapai. Keadaan ajeg ditandai oleh nilai suhu (uapgas, dinding, dan pendingin) yang relatif tetap, sebagaimana ditunjukkan pada Gambar 2, yaitu setelah proses berlangsung sekitar 700 sekon.

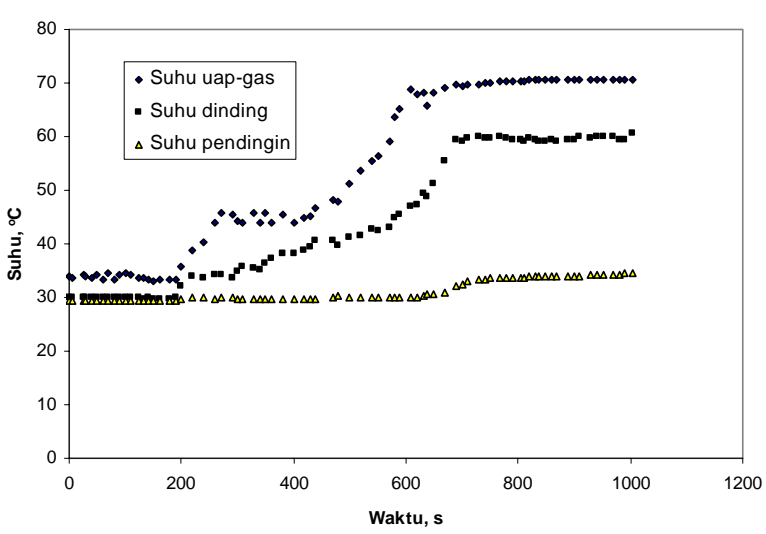

Gambar 2. Pemantauan nilai suhu untuk memastikan kondisi ajeg tercapai

Data yang diperoleh dari pengukuran langsung meliputi suhu (uap-gas, air pendingin, dan dinding kondensor), tekanan, dan kecepatan alir (udara, air pendingin, dan kondensat). Tekanan diukur dengan menggunakan pressure tranducer. Adapun kecepatan alir udara dan air pendingin diukur dengan menggunakan flowmeter jenis rotameter, sedangkan kecepatan alir kondensat diukur dengan menggunakan penampung berskala. Sampel uap-gas diambil untuk kemudian dianalisis dengan Gas Chromatography Shimadzu dengan kolom 10\% Carbowax 1500 on chromosorb, 40/60.

Data hasil percobaan diolah untuk mendapatkan koefisien perpindahan panas dan massa dengan bantuan neraca kalor dan massa dalam bentuk model 
matematik, yaitu Model Perpindahan Kalor Linear Terkoreksi dan Model Perpindahan Massa Linear Terkoreksi sebagaimana ditunjukkan pada Persamaan (1) dan (2), serta model perubahan suhu air pendingin.

$$
\begin{gathered}
-\mathrm{GC}_{\mathrm{p}} \frac{\mathrm{dT}_{\mathrm{g}}}{\mathrm{dA}}=\mathrm{h}_{\mathrm{g}}^{*}\left(\mathrm{~T}_{\mathrm{g}}-\mathrm{T}_{\mathrm{s}}\right) \\
-\frac{\mathrm{dV}_{\mathrm{i}}}{\mathrm{dA}}=\mathrm{k}_{\mathrm{gi}}^{*}\left(\mathrm{P}_{\mathrm{gi}}-\mathrm{P}_{\mathrm{si}}\right)
\end{gathered}
$$

Persamaan-persamaan tersebut diselesaikan cara Runge-Kutta. Data kecepatan dan suhu umpan, kecepatan dan suhu keluar air pendingin, tekanan sistem dipakai sebagai masukan, lengkap dengan dimensi kondensor dan sifat bahan. Nilai koefisien perpindahan massa dan koefisien perpindahan kalor mula-mula diduga pada suatu nilai tertentu untuk kemudian diperbaiki dengan cara mengevaluasi perbedaan antara data dan hasil hitungan peubah yang dioptimasi, yaitu komposisi uap-gas, suhu uap-gas, dan suhu air pendingin. Perbaikan nilai (optimasi) dilakukan dengan cara Hooke-Jeeves. Disamping itu, kebenaran hasil perhitungan dievaluasi dengan mempertimbangkan hasil perhitungan suhu, yaitu suhu air pendingin, dinding kondensor, suhu permukaan luar kondensat, dan suhu uap-gas.

Hasil estimasi nilai koefisien perpindahan panas dan massa pada persamaan pada berbagai kondisi percobaan disusun dalam bentuk persamaan bilangan tidak berdimensi berikut.

$$
\begin{gathered}
\mathrm{Nu}=\mathrm{A}(1-\mathrm{yn})^{\mathrm{B}} \operatorname{Re}^{\mathrm{C}} \operatorname{Pr}^{1 / 3} \\
\mathrm{Sh}_{1}=\alpha_{1}(1-\mathrm{yn})^{\beta 1} \operatorname{Re}^{\gamma 1} \mathrm{Sc}^{1 / 3} \\
\mathrm{Sh}_{2}=\alpha_{2}(1-\mathrm{yn})^{\beta 2} \operatorname{Re}^{\gamma 2} \mathrm{Sc}^{1 / 3}
\end{gathered}
$$

Dengan A, B, C, $\alpha, \beta$, dan $\gamma$ merupakan tetapan yang dicari dari percobaan.

\section{HASIL DAN PEMBAHASAN}

Percobaan dilakukan sebanyak 11 kali dengan contoh data ditunjukkan pada Tabel 1, yaitu data percobaan dengan tekanan campuran uap-gas, debit air pendingin, debit campuran udara, dan debit kondensat berturut-turut adalah 0,03 psig, 2,8 L/men, $978 \mathrm{cc} / \mathrm{men}$, dan $175 \mathrm{cc} / \mathrm{men}$. Suhu campuran uap-gas lebih kecil daripada titik didih masing-masing komponennya, sehingga pengembunan kedua uap dapat terjadi sejak masuk kondensor yang didukung oleh terjadinya penurunan fraksi mol kedua uap sejak awal yang besarnya hampir sama.

Suhu campuran uap-gas sepanjang kondensor sistem metanol-propanol-udara mempunyai kemiripan dengan suhu campuran sepanjang kondensor untuk sistem etanol-benzen-udara (Sarto dkk., 2002) dan etanol-toluen-udara (Sarto dkk., 2008). Perbedaannya terjadi pada nilai suhu masuknya, yaitu untuk Sistem etanol-benzen-udara dan Sistem etanol-toluen-udara masing-masing sekitar 70 dan $77^{\circ} \mathrm{C}$, sedangkan untuk Sistem metanol-propanol-udara sekitar $72,5^{\circ} \mathrm{C}$. Hal ini disebabkan oleh perbedaan titik didih komponenkomponen campuran tersebut, yaitu untuk toluen, propanol, benzen, etanol, dan metanol berturut-turut sebesar 110; 82,2; 80; 78,2; dan $64,4^{\circ} \mathrm{C}$ (Reid et al., 1987). Akan tetapi, suhu campurannya sangat berbeda dengan sistem metanol-air-udara, sebagaimana perbedaan sistem metanol-air-udara dengan 2 sistem yang lain (Sarto, 2008(b)).

Berdasarkan data yang didapatkan dan persamaan-persamaan yang diperoleh dari neraca panas dan massa beserta persamaan-persamaan terkait sifat alat dan bahan, nilai Koefisien Perpindahan Panas Terkoreksi $\left(\mathrm{h}^{*}\right)$, Koefisien Perpindahan Massa Metanol Terkoreksi $\left(\mathrm{kg}_{\mathrm{m}}{ }^{*}\right)$, dan Koefisien Perpindahan Massa Propanol Terkoreksi $\left(\mathrm{kg}_{\mathrm{p}}{ }^{*}\right)$ dapat diperoleh, sebagaimana ditunjukkan pada Tabel 2.

Tabel 1. Contoh Data percobaan pengembunan campuran metanol-propanol-udara

\begin{tabular}{ccccccc}
\hline Posisi & $\mathrm{T}_{\mathrm{g}},{ }^{\circ} \mathrm{C}$ & $\mathrm{T}_{\mathrm{c}},{ }^{\circ} \mathrm{C}$ & $\mathrm{T}_{\mathrm{w}},{ }^{\circ} \mathrm{C}$ & $\mathrm{y}_{\mathrm{m}}$ & $\mathrm{y}_{\mathrm{p}}$ & $\mathrm{y}_{\mathrm{n}}$ \\
\hline 1 & 72,25 & 40,48 & 64,82 & 0,7983 & 0,1510 & 0,0410 \\
2 & 72,24 & 40,26 & 60,71 & 0,8149 & 0,1385 & 0,0466 \\
3 & 72,21 & 38,29 & 59,02 & 0,8057 & 0,1339 & 0,0602 \\
4 & 71,73 & 36,45 & 57,37 & 0,8030 & 0,1310 & 0,0660 \\
5 & 70,92 & 35,58 & 53,15 & 0,8148 & 0,1140 & 0,0712 \\
6 & 67,53 & 33,77 & 44,50 & 0,8029 & 0,1075 & 0,0896 \\
7 & 61,03 & 31,18 & & 0,8090 & 0,0847 & 0,1064 \\
\hline
\end{tabular}

Tabel 2. Hasil perhitungan nilai koefisien perpindahan panas $\left(\mathrm{h}^{*}\right)$ dan massa $\left(\mathrm{kg}_{\mathrm{m}}{ }^{*}, \mathrm{~kg}_{\mathrm{p}}{ }^{*}\right)$

\begin{tabular}{cccccc}
\hline $\begin{array}{c}\text { No } \\
\text { Percobaan }\end{array}$ & Fraksi Udara & $\begin{array}{c}\text { Posisi } \\
\text { Sampling }\end{array}$ & $\mathrm{h}^{*}, \mathrm{~J} /\left(\mathrm{m}^{2} \mathrm{~K}\right)$ & $\mathrm{kg}_{\mathrm{m}}{ }^{*}, \mathrm{kmol} /\left(\mathrm{m}^{2} \mathrm{~s}\right)$ & $\mathrm{kg}_{\mathrm{p}}{ }^{*}, \mathrm{kmol}^{\prime}\left(\mathrm{m}^{2} \mathrm{~s}\right)$ \\
\hline 31 & 0,0208 & 1 & 5,436 & 9,949 & 1,496 \\
& 0,0231 & 2 & 4,869 & 9,433 & 0,972 \\
& 0,0262 & 3 & 4,976 & 6,384 & 0,708 \\
& 0,0290 & 4 & 3,992 & 5,520 & 0,685 \\
& 0,0309 & 5 & 5,890 & 3,926 & 0,705 \\
& 0,0342 & 6 & 7,600 & 3,570 & 0,556 \\
\hline
\end{tabular}


Reaktor, Vol. 13 No. 2, Desember 2010, Hal. 109-116

\begin{tabular}{|c|c|c|c|c|c|}
\hline \multirow[t]{7}{*}{32} & 0,0172 & 1 & 8,112 & 11,409 & 2,484 \\
\hline & 0,0212 & 2 & 6,628 & 9,646 & 2,087 \\
\hline & 0,0250 & 3 & 5,976 & 8,116 & 1,668 \\
\hline & 0,0284 & 4 & 4,389 & 7,905 & 1,457 \\
\hline & 0,0336 & 5 & 3,495 & 6,545 & 1,468 \\
\hline & 0,0383 & 6 & 5,894 & 7,065 & 0,666 \\
\hline & 0,0437 & 7 & 2,955 & 5,439 & 0,701 \\
\hline \multirow[t]{7}{*}{33} & 0,0123 & 1 & 8,595 & 10,512 & 5,026 \\
\hline & 0,0115 & 2 & 13,645 & 18,260 & 4,753 \\
\hline & 0,0129 & 3 & 8,489 & 9,302 & 1,543 \\
\hline & 0,0148 & 4 & 5,812 & 4,086 & 1,547 \\
\hline & 0,0183 & 5 & 5,355 & 3,908 & 1,177 \\
\hline & 0,0206 & 6 & 5,005 & 2,890 & 0,754 \\
\hline & 0,0246 & 7 & 3,951 & 2,100 & 0,737 \\
\hline \multirow[t]{7}{*}{34} & 0,0045 & 1 & 6,500 & 17,080 & 4,996 \\
\hline & 0,0067 & 2 & 5,143 & 11,680 & 4,186 \\
\hline & 0,0092 & 3 & 9,080 & 11,391 & 3,983 \\
\hline & 0,0149 & 4 & 7,119 & 5,790 & 2,261 \\
\hline & 0,0304 & 5 & 4,269 & 4,091 & 1,254 \\
\hline & 0,0331 & 6 & 3,191 & 2,574 & 0,813 \\
\hline & 0,0494 & 7 & 2,566 & 2,467 & 0,369 \\
\hline \multirow[t]{7}{*}{35} & 0,0078 & 1 & 19,055 & 19,160 & 4,243 \\
\hline & 0,0102 & 2 & 14,654 & 6,757 & 2,652 \\
\hline & 0,0118 & 3 & 9,707 & 8,150 & 1,911 \\
\hline & 0,0138 & 4 & 7,397 & 6,955 & 1,749 \\
\hline & 0,0161 & 5 & 6,875 & 5,897 & 1,406 \\
\hline & 0,0181 & 6 & 4,419 & 5,276 & 1,395 \\
\hline & 0,0204 & 7 & 4,294 & 3,205 & 0,801 \\
\hline \multirow[t]{7}{*}{36} & 0,0177 & 1 & 12,234 & 13,239 & 1,979 \\
\hline & 0,0244 & 2 & 10,999 & 10,891 & 2,512 \\
\hline & 0,0323 & 3 & 5,570 & 9,984 & 2,391 \\
\hline & 0,0397 & 4 & 6,967 & 8,406 & 2,836 \\
\hline & 0,0480 & 5 & 4,589 & 6,626 & 1,405 \\
\hline & 0,0595 & 6 & 3,210 & 4,132 & 1,189 \\
\hline & 0,0628 & 7 & 3,557 & 2,502 & 0,502 \\
\hline \multirow[t]{7}{*}{37} & 0,0234 & 1 & 13,894 & 11,403 & 2,379 \\
\hline & 0,0253 & 2 & 9,252 & 5,624 & 1,748 \\
\hline & 0,0285 & 3 & 11,410 & 4,126 & 1,659 \\
\hline & 0,0317 & 4 & 12,916 & 4,942 & 3,682 \\
\hline & 0,0355 & 5 & 6,233 & 3,834 & 1,262 \\
\hline & 0,0412 & 6 & 8,520 & 4,310 & 3,890 \\
\hline & 0,0445 & 7 & 9,779 & 5,653 & 1,386 \\
\hline \multirow[t]{7}{*}{56} & 0,0410 & 1 & 33,000 & 76,913 & 1,595 \\
\hline & 0,0466 & 2 & 16,076 & 20,734 & 1,428 \\
\hline & 0,0602 & 3 & 2,141 & 3,014 & 1,318 \\
\hline & 0,0660 & 4 & 1,601 & 1,638 & 0,434 \\
\hline & 0,0712 & 5 & 1,979 & 1,655 & 0,657 \\
\hline & 0,0896 & 6 & 3,702 & 1,634 & 1,706 \\
\hline & 0,1064 & 7 & 0,613 & 1,001 & 2,399 \\
\hline \multirow[t]{7}{*}{57} & 0,0093 & 1 & 19,127 & 16,759 & 4,796 \\
\hline & 0,0170 & 2 & 8,486 & 8,051 & 4,918 \\
\hline & 0,0234 & 3 & 3,491 & 4,234 & 2,163 \\
\hline & 0,0263 & 4 & 3,060 & 6,258 & 1,608 \\
\hline & 0,0291 & 5 & 3,301 & 6,899 & 1,253 \\
\hline & 0,0516 & 6 & 3,491 & 2,195 & 1,198 \\
\hline & 0,0719 & 7 & 2,236 & 10,954 & 1,018 \\
\hline \multirow[t]{4}{*}{58} & 0,0085 & 1 & 12,883 & 60,000 & 5,392 \\
\hline & 0,0141 & 2 & 10,313 & 32,997 & 4,933 \\
\hline & 0,0180 & 3 & 4,389 & 6,098 & 2,770 \\
\hline & 0,0198 & 4 & 4,389 & 3,379 & 2,699 \\
\hline
\end{tabular}




\begin{tabular}{cccccc}
\hline & 0,0201 & 5 & 4,788 & 3,625 & 2,716 \\
0,0217 & 6 & 8,030 & 9,036 & 2,961 \\
& 0,0241 & 7 & 5,716 & 3,797 & 2,919 \\
& & 5,760 & 2,783 & 2,187 \\
\hline 59 & 0,0077 & 1 & 23,312 & 18,658 & 4,730 \\
& 0,0112 & 2 & 16,066 & 6,609 & 3,528 \\
& 0,0172 & 3 & 7,014 & 5,191 & 2,211 \\
0,0216 & 4 & 3,591 & 4,938 & 1,010 \\
0,0220 & 5 & 5,669 & 2,718 & 0,833 \\
0,0225 & 6 & 4,162 & 2,421 & 0,634 \\
\hline
\end{tabular}

Dengan memvariasi kondisi umpan kondensor sebanyak 11 macam, data hasil percobaan menunjukkan bahwa rentang nilai perubahan bilangan Reynolds dan bilangan Nusselt berturut-turut sebesar 1200-15500 dan 1300-80000, yang hubungannya dapat dilihat pada Gambar 3.

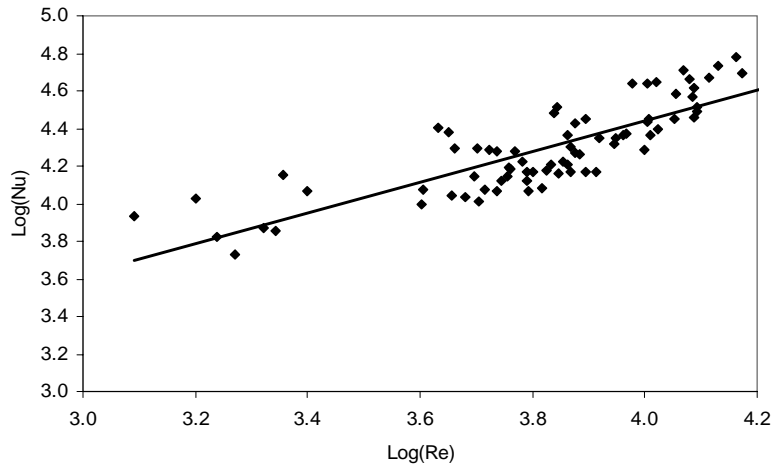

Gambar 3. Hubungan antara bilangan Nusslet dan bilangan Reynolds sistem Metanol-Propanol-Udara

Berdasarkan gambar tersebut dan memperhatikan pengaruh jumlah udara, maka hubungan antara bilangan Nusselt dengan bilangan Reynolds Sistem metanol-propanol-udara mengikuti Persamaan (6).

$$
\mathrm{Nu}=19,9297\left(1-\mathrm{y}_{\mathrm{n}}\right)^{2,9164} \operatorname{Re}^{0,8142} \operatorname{Pr}^{1 / 3}
$$

dengan bilangan Prandtl sebesar 0,856, dan standar deviasi sebesar $35,12 \%$.

Nilai tetapan pada Persamaan (6) dekat dengan nilai tetapan untuk sistem etanol-benzen-udara dan Sistem etanol-toluen-udara, tetapi nilai tersebut jauh lebih kecil daripada nilai tetapan untuk Sistem metanolair-udara. Perbedaan Sistem metanol-air-udara dengan ketiga sistem yang lain sesuai dengan perbedaan nilai koefisien perpindahan kalor keseluruhan yang ditunjukkan pada Tabel 8 oleh Kern (1950).

Rentang perubahan bilangan Sherwood Sistem metanol-propanol-udara ditunjukkan pada 13 percobaan antara 1600 dan 63000. Hubungan antara bilangan Reynold dan bilangan Sherwood ditunjukkan pada Gambar 4 dan 5, dan dengan memperhatikan komposisi udara pada masing-masing percobaan, akan diperoleh Persamaan (7) dan Persamaan (8) berturutturut untuk metanol dan propanol.

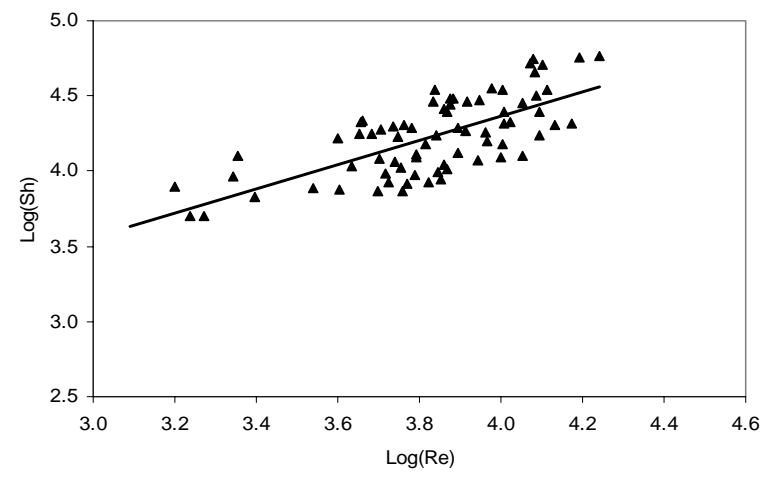

Gambar 4. Hubungan antara Bilangan Sherwood Metanol dan Bilangan Reynolds Sistem MetanolPropanol-Udara

$$
\mathrm{Sh}_{1}=15,1042\left(1-\mathrm{y}_{\mathrm{n}}\right)^{2,9696} \mathrm{Re}^{0,8068} \mathrm{Sc}^{1 / 3}
$$

dengan bilangan Schmidt sebesar 0,946, dan standar deviasi sebesar $38,99 \%$.

$$
\mathrm{Sh}_{2}=5,7227\left(1-\mathrm{y}_{\mathrm{n}}\right)^{2,9916} \mathrm{Re}^{0,8113} \mathrm{Sc}^{1 / 3}
$$

dengan bilangan Schmidt sebesar 1,374, dan standar deviasi sebesar 39,11\%.

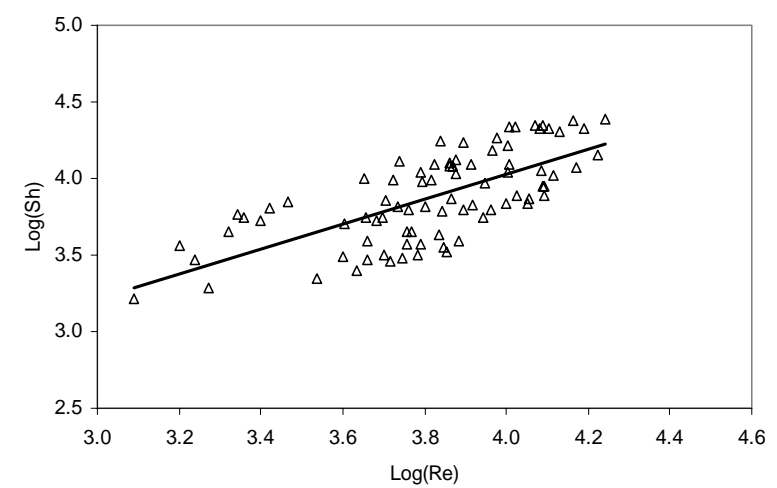

Gambar 5. Hubungan antara Bilangan Sherwood Propanol dan Bilangan Reynolds Sistem MetanolPropanol-Udara

Bilangan Sherwood metanol (persamaan 7) mempunyai nilai tetapan yang berbeda dengan Bilangan Sherwood metanol Sistem metanol-airudara. Nilai A sistem ini $(15,1042)$ lebih kecil daripada nilai A pada Sistem metanol-air-udara $(25,595)$, tetapi Nilai B sistem ini $(2,9696)$ sedikit lebih besar daripada nilai B Sistem metanol-air-udara 
$(2,8423)$ dengan nilai $\mathrm{C}$ yang hampir sama, yaitu 0,8068 dan 0,8097. Oleh karena itu, untuk kedua sistem tersebut, nilai Bilangan Sherwood metanol sistem ini lebih kecil daripada nilai tersebut untuk sistem metanol-air-udara. Hal ini disebabkan oleh pengaruh interaksi dengan pasangannya, sistem ini metanol berpasangan dengan propanol yang mempunyai difusifitas hampir sama, yaitu sekitar $0,088 \mathrm{~cm}^{2} / \mathrm{s}$, sedangkan sistem metanol-air-udara metanol berpasangan dengan air yang mempunyai difusifitas lebih dari 2 kalinya, yaitu $0,282 \mathrm{~cm}^{2} / \mathrm{s}$.

\section{KESIMPULAN}

Berdasarkan pada hasil penelitian dan pembahasan dapat diambil kesimpulan bahwa persamaan semi empirik koefisien perpindahan panas dalam bentuk bilangan tak berdimensi untuk sistem metanol-propanol-udara adalah $\mathrm{Nu}=19,9297(1-$ $\left.\mathrm{y}_{\mathrm{n}}\right)^{2,9164} \operatorname{Re}^{0,8142} \operatorname{Pr}^{1 / 3}$ dengan standard deviasi sebesar $35,12 \%$. Hubungan semi empirik koefisien perpindahan massa dalam bentuk bilangan tak berdimensi untuk untuk sistem metanol-propanol-udara adalah $\mathrm{Sh}_{1}=15,1042\left(1-\mathrm{y}_{\mathrm{n}}\right)^{2,9696} \mathrm{Re}^{0,8068} \mathrm{Sc}^{1 / 3}$ dan $\mathrm{Sh}_{2}=5,7227(1-$ $\left.\mathrm{y}_{\mathrm{n}}\right)^{2,9916} \mathrm{Re}^{0,8113} \mathrm{Sc}^{1 / 3}$ dengan standar deviasi masingmasing sebesar 38,99 dan 39,11\%.

\section{DAFTAR NOTASI}

$\mathrm{A}=$ luas, $\mathrm{m}^{2}$

$\mathrm{C}_{\mathrm{p}}=$ kapasitas panas uap, $\mathrm{J} /(\mathrm{kg} \mathrm{K})$

$\mathrm{G}=$ kecepatan molar uap, $\mathrm{kmol} /\left(\mathrm{m}^{2} \mathrm{~s}\right)$

$\mathrm{h}_{\mathrm{g}}{ }^{*}=$ koefisien perpindahan kalor terkoreksi , $\mathrm{J} /\left(\mathrm{m}^{2} \mathrm{~K}\right)$

$\mathrm{k}_{\mathrm{g}}{ }^{*}=$ koefisien perpindahan massa terkoreksi, kmol/ $\left(\mathrm{m}^{2} \mathrm{~s}\right)$

$\mathrm{Nu}=$ Bilangan Nusslet, tidak berdimensi

$\mathrm{P}_{\mathrm{gi}}=$ tekanan parsial komponen uap $\mathrm{i}, \mathrm{N} / \mathrm{m}^{2}$

$\operatorname{Pr}=$ Bilangan Prandtl, tidak berdimensi

$\mathrm{P}_{\mathrm{si}}=$ tekanan parsial komponen i pada interface, $\mathrm{N} / \mathrm{m}^{2}$

$\operatorname{Re}=$ Bilangan Reynolds, tidak berdimensi

$\mathrm{Sc}=$ Bilangan Schmidt, tidak berdimensi

$\mathrm{Sh}=$ Bilangan Sherwood, tidak berdimensi

$\mathrm{T}_{\mathrm{g}}=$ suhu gas, $\mathrm{K}$

$\mathrm{T}_{\mathrm{s}}=$ suhu batas uap-kondensat (interface), $\mathrm{K}$

$\mathrm{Tc}=$ suhu air pendingin, $\mathrm{C}$

$\mathrm{Tw}=$ suhu dinding, $\mathrm{C}$

$\mathrm{V}_{\mathrm{i}}=$ kecepatan mol masing-masing komponen, $\mathrm{kmol} / \mathrm{s}$

$\mathrm{y}_{\mathrm{m}}=$ fraksi mol uap metanol

$\mathrm{y}_{\mathrm{n}}=$ fraksi mol gas

$\mathrm{y}_{\mathrm{p}}=$ fraksi mol uap propanol

\section{DAFTAR PUSTAKA}

Behren, G.L.V., Jones, W.O., and Wasa, D.T., (1972), Multicomponent Mass Transfer in Turbulence Flow, A.I.Ch.E. Journal, Vol. 18, no. 1, pp. 25-30.

Burghardt, A. and Berezowski, M., (1992), Comparison of Various Mass Transport Model in Multicomponent Condensation, Chem. Eng. and Processing, vol. 31, pp. 161-171.
Gocken, G. and Yildirim, N., (2008), Effect of NonCondensable Gasses on Geothermal Power Plant Performance. Case Study : Kizildere Geothermal Power Plant-Turkey, International Journal of Exergy, vol 5, no. 5-6, hal 684-695.

Kern, D.Q., (1950), Process Heat Transfer, International Student Edition, McGraw-Hill Kogakusha, Ltd., Tokyo, p 840.

Krishna, R. and Panchal, C.B., (1977), Condensation of Binary Vapour Mixture in he Presence of an Inert Gas, Chem. Eng. Sci., vol. 32, pp. 741-745.

Krishna, G. and Standart, G.L., (1976), A Multicomponent Film Model Incorporating a General Matrix Methode of Solution to the Maxwell-Stefan Equation, A.I.Ch.E Journal, vol. 22, no. 2, pp. 383389.

Lee, H. and Kim, M., (2001), The Effect of NonCondensable Gas on Diect Contact Condensation of Steam/Air Mixture, Journal of the Korean Nuclear Society, vol. 33, no. 6, hal. 585-595.

Mazzarotta, B. and Sebastian, E., (1995), Process Design of Condenser for Vapor Mixtures in the Presence of Non Condensable Gases, The Canadian Journal of Chem. Eng., Vol. 73, pp. 456-461.

Reid, R.C., Prausnitz, J.M., and Paling, B.E., (1987), The properties of Gases and Liquids, $4^{\text {th }}$ ed., McGraw Hill, New York.

Sarto, Soehendro, B., Bendiyasa, I.M., dan Rochmadi, (2002), Perpindahan Panas dan Massa pada Pengembunan Campuran Etanol-Benzen-Udara dalam Kondensor Tegak, Forum Teknik, Jilid 26, no. 2, hal. 124-133.

Sarto, Soehendro, B., Bendiyasa, I.M., dan Rochmadi, (2008 (a)), Perpindahan Panas dan Massa pada Pengembunan Campuran Etanol-Toluen-Udara dalam Kondensor Tegak, Seminar Nasional Teknik Kimia "Kejuangan".

Sarto, Soehendro, B., Bendiyasa, I.M., dan Rochmadi, (2008 (b)), Perpindahan Panas dan Massa pada Pengembunan Campuran Metanol-Air-Udara dalam Kondensor Tegak, Media Teknik, no. 3, pp. 36-366.

Schrodt, J.T., (1973), Simultaneous Heat and Mass Transfer from Multicomponent Condensing VapourGas Systems, A.I.Ch.E. Journal, vol. 19, no. 4, pp. 753-754.

Takaharu, T. and Yurika, N., (2003), TED-AJ03 Effect of Non-Condensable Gas on Experimental Value of Condensation Coefficient, Proceedings of the ASME/JSME Thermal Engineering Joint Conference. 
Taylor, R. and Krishna, R., (1993), Multicomponent Mass Transfer, John Wiley \& Sons, New York, hal. 435-477.

Toor, H.L., (1964), Solution of the Linearized Equation of Multicomponent Mas Transfer: 1, A.I.Ch.E. Journal, vol. 10 , no.4, pp. 448-455.

Wang, S. and Utaka, Y., (2004), Effect of NonCondensable Gas Mass Fraction on Condensation Heat Transfer for Water-Ethanol Vapor Mixture, JSME International Journal, vol. 47, no. 2, hal. 162-167.
Wang, S. and Utaka, Y., (2005), An Experimental Study on the Effect of Non Condensable Gas for Solutal Marangoni Condensation Heat Transfer, Experimental Heat Transfer, vol 18, hal 61-79.

Webb, D.R. and Sardesai, R.G., (1981), Vertical of Multicomponent Mass Transfer Model for Condensation Inside a Vertical Tube, Int. J. Multiphase Flow, vol. 7, no. 5, hal. 507-520. 